\title{
Comparisons of Soil Properties, Enzyme Activities and Microbial Communities in Heavy Metal Contaminated Bulk and Rhizosphere Soils of Robinia pseudoacacia L. in the Northern Foot of Qinling Mountain
}

\author{
Yurong Yang ${ }^{1}$, Miao Dong ${ }^{1}$, Yaping Cao ${ }^{1}$, Jinlong Wang ${ }^{1}$, Ming Tang ${ }^{2,3, *}$ and Yihui Ban ${ }^{3}$ \\ 1 State Environmental Protection Key Laboratory of Wetland Ecology and Vegetation Restoration, \\ Key Laboratory of Vegetation Ecology, School of Environment, Northeast Normal University, \\ Changchun 130117, China; yangyr422@nenu.edu.cn (Y.Y.); dongm005@nenu.edu.cn (M.D.); \\ caoyp050@nenu.edu.cn (Y.C.); wangj1215@nenu.edu.cn (J.W.) \\ 2 State Key Laboratory for Conservation and Utilization of Subtropical Agro-Bioresources (South China \\ Agricultural University), Guangdong Key Laboratory for Innovative Development and Utilization of Forest \\ Plant Germplasm, College of Forestry and Landscape Architecture, South China Agricultural University, \\ Guangzhou 510642, China \\ 3 College of Forestry, Northwest A\&F University, Yangling 712100, China; banyihui7500@163.com \\ * Correspondence: tangmingyl@163.com; Tel./Fax: +86-029-8708-0807
}

Received: 22 September 2017; Accepted: 7 November 2017; Published: 12 November 2017

\begin{abstract}
The toxic effects of heavy metal (HM) contamination on plant metabolism and soil microorganisms have been emphasized recently; however, little is known about the differences in soil physical, chemical, and biological properties between bulk and rhizosphere soils contaminated with HMs in forest ecosystem. The present study was conducted to evaluate the rhizosphere effect on soil properties, enzyme activities and bacterial communities associated with Robinia pseudoacacia L. along a HM contamination gradient. Soil organic matter (SOM), available nitrogen (AN) and phosphorus (AP) contents were significantly higher in rhizosphere soil than those in bulk soil at HM contaminated sites $(p<0.05)$. Compared to bulk soil, activities of four soil enzymes indicative of $\mathrm{C}$ cycle ( $\beta$-glucosidase), $\mathrm{N}$ cycle (protease, urease) and $\mathrm{P}$ cycle (alkaline phosphatase) in rhizosphere soil across all study sites increased by $47.5 \%, 64.1 \%, 52.9 \%$ and $103.8 \%$, respectively. Quantitative PCR (qPCR) and restriction fragment length polymorphism (RFLP) were used to determine the relative abundance, composition and diversity of bacteria in both bulk and rhizosphere soils, respectively. The copy number of bacterial 16S rRNA gene in bulk soil was significantly lower than that in rhizosphere soil $(p<0.05)$, and it had significantly negative correlations with total/DTPA-extractable $\mathrm{Pb}$ concentrations $(p<0.01)$. Alphaproteobacteria, Gammaproteobacteria and Firmicutes were the most dominant groups of bacteria at different study sites. The bacterial diversity index of Species richness $(S)$ and Margalef $\left(d_{M a}\right)$ were significantly higher in rhizosphere soil compared with those in bulk soil, although no difference could be found in Simpson index $(D)$ between bulk and rhizosphere soils $(p>0.05)$. Redundancy analysis (RDA) results showed that soil $\mathrm{pH}, \mathrm{EC}, \mathrm{SOM}$ and total/DTPA-extractable $\mathrm{Pb}$ concentrations were the most important variables affecting relative abundance, composition and diversity of bacteria $(p<0.05)$. Our study highlights the importance of rhizosphere effect on soil nutrient content, enzyme activity, bacterial abundance and community in HM contaminated forest soils. Further study is still required to understand the specific processes in the rhizosphere to achieve a suitable rhizosphere biotechnology for restoration of degraded forest ecosystem.
\end{abstract}

Keywords: heavy metal contamination; bulk and rhizosphere soils; enzyme activity; bacterial community 


\section{Introduction}

Soil heavy metal (HM) contamination has become one of the most severe environmental issues in many parts of the world because of their toxic effects on the environment and human health [1-3]. HMs in soil are derived from both the natural (parent material) and various anthropogenic sources [4]. The major anthropogenic sources of this pollution are mining, smelting, industrial activities and the application of fertilizers or pesticides [5]. In recent years, with the rapid development of society and economy, soil polluted with HMs has become a serious and widespread environmental issue in China [6,7]. Unlike organic pollutants, HMs are more toxic, non-biodegradable in the environment and can easily accumulated and magnified in organisms [8]. This kind of pollutant not only degrades ecosystem services but also threatens human health through the food chain [9].

Soil enzymes are mainly of microbial origin, being derived from intracellular, cell-associated or free enzymes [10]. They are important in catalyzing several vital reactions necessary for the life processes of microorganisms in soils and the stabilization of soil structure, the decomposition of organic wastes, organic matter formation, and nutrient cycling, hence playing an important role in maintaining soil ecology, physical and chemical properties, fertility, and soil health [11]. Soil enzyme activities, reacting faster than physical variables and/or after any chemical change in the soil, have been generally considered as one of a good bioindicators of soil fertility quality and can quantify changes as a result of the natural and anthropogenic disturbance in the soil ecosystem [12]. Therefore, a better understanding of the effects of HM on soil enzyme activities will potentially provide an opportunity for an integrated assessment of soil biology. Vig et al. [13] indicated that HMs could inhibit soil enzyme activities through interacting with the enzyme active sites and substrate complexes, and denaturing the enzyme protein. The results of Brookes [14] reported that dehydrogenase activity could be considered as an indicator of soil contaminated with HM. Liao and Huang [15] have succeeded in using urease, protease and acid phosphatase as indices of soil contamination by HMs. Although there are increasing studies on soil enzymes, little information has been reported on the link between soil enzyme activities and bacterial community structure along the gradient of HM concentration in black-locust (Robinia pseudoacacia L.) forest on the Loess Plateau.

However, the influence of HM on soil enzyme activity depends on $\mathrm{pH}$, nutrient form and amount, HM concentration and availability, enzyme type, etc. [16]. Acosta-Martinez and Tabatabai [17] reported that $\beta$-glucosidase was sensitive to $\mathrm{pH}$ changes, which can be used as a good biochemical indicator for evaluating ecological changes resulting from soil acidification. Apart from being good indicators of soil fertility, phosphatase secretion from both plant roots and soil microorganisms can increase to improve the solubilization and remobilization of phosphate and affect the ability of the plant to cope with P-stressed conditions [18]. Studies have shown that urease was very sensitive to toxic concentrations of HMs, and its activity generally increased with increasing temperature [19].

On the other hand, the rhizosphere is an interface or zone of soil surrounding to plant roots and has important effects on plant health and soil quality. The living plant roots are able to secrete large quantity of organic compounds that promote the growth of bacteria, resulting in a higher bacterial community, diversity and enzyme activities in rhizosphere compared with bulk soil [20]. In turn, these beneficial microorganisms are capable of improving plant growth through enhancing nutrient uptake, producing auxins-like substances and protecting them from abiotic stresses [21]. The net carbon and nitrogen mineralization and nitrification rates, activities of extracellular enzymes for nutrient cycling in rhizosphere are generally higher than these in bulk soil [22,23]. Therefore, to better understand the mechanism of phytoremediation and highlight the importance of rhizosphere effects on ecological restoration, it is essential to compare the differences in microbial composition, soil properties and extracellular enzyme activities between rhizosphere and bulk soils in HM contaminated soils.

In our previous investigation, $R$. pseudoacacia had been identified as lead/zinc tolerant dominant tree species widely distributed in HM contaminated soils in Feng County [24]. This tree was considered as a suitable candidate for phytoremediation owing to its developed root system, high biomass productivity, environmental stress tolerance and ability of atmospheric nitrogen fixation [24-26]. 
However, the information about the rhizosphere effects of R. pseudoacacia on bacterial community, soil properties and activities extracellular enzymes is still unknown, which limits our understanding of phytoremediation processes in HM polluted soils. Therefore, the objectives of this study were to (1) determine the differences of soil properties, enzyme activities, bacterial abundance and diversity between bulk and rhizosphere soils; (2) evaluate the impacts of rhizosphere and HM pollution on soil properties, enzyme activities, bacterial abundance and diversity; and (3) reveal the influences of soil properties on bacterial composition in both HM contaminated rhizosphere and bulk soils in Feng County, Northwest China. The findings of this study attempted to provide a better understanding of and new insights into the influences of rhizosphere effects on soil biology in $\mathrm{Pb}-\mathrm{Zn}$ mine area.

\section{Materials and Methods}

\subsection{Study Area and Sampling}

This study was conducted in Qiandongshan $\mathrm{Pb}-\mathrm{Zn}$ mine region, located in the Northern foot of Qinling Mountain, Shaanxi Province, Northwest part of China $\left(106^{\circ} 38^{\prime}\right.$ E, $\left.33^{\circ} 49^{\prime} \mathrm{N}\right)$. This region is in the warm temperate semiarid zone with an annual average temperature of $11.4^{\circ} \mathrm{C}$. The annual average rainfall is $613.2 \mathrm{~mm}$ with a frost-free period of 188 days. The soil texture was classified as cinnamon and brunisolic soil, according to the traditional soil genesis classification standard in China [27]. Qiandongshan $\mathrm{Pb}-\mathrm{Zn}$ region is the largest and the most typical five $\mathrm{Pb}$ and $\mathrm{Zn}$ producers in China, and its total reserve is approximately $1.12 \times 10^{6}$ tons [28].

The HM polluted area had the same soil type and was divided into polluted levels of light $\left(\mathrm{S} 1,33^{\circ} 51.971^{\prime} \mathrm{N}, 106^{\circ} 39.311^{\prime} \mathrm{E}\right)$, low $\left(\mathrm{S} 2,33^{\circ} 51.034^{\prime} \mathrm{N}, 106^{\circ} 38.646^{\prime} \mathrm{E}\right)$, medium $\left(\mathrm{S} 3,33^{\circ} 51.288^{\prime} \mathrm{N}\right.$,

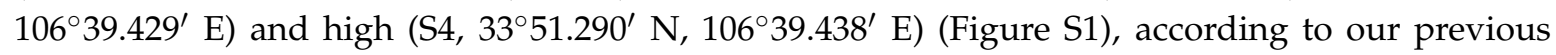
investigation and the Chinese environmental quality standard (Grade II) for soils (GB 15618-1995) [27,29-31]. In August 2012, four study plots $(15 \times 15 \mathrm{~m})$ dominated by target tree species $(R$. pseudoacacia) were identified at each site for soil sampling. The pits at three subplots within each plot were excavated to collect sufficient amount of rhizosphere soil and bulk soil. Samples collected from subplots were finally combined into one composite sample, and the parameters were measured in quadruplicate for each study site. Individual soil samples were kept in separate plastic bags and placed in a cooler with ice until they arrived at the laboratory for processing. In the laboratory, the volume of soil adhering to closely to plant fine roots defined as rhizosphere soil, while the remaining soil classified as bulk soil. Portions of rhizosphere and bulk soil samples were used for DNA extraction and analysis of enzyme activity, and the remaining soil samples were used for soil properties determination.

\subsection{Soil Properties}

After air-drying, the soil samples were ground to a fine powder and sieved through an 80-mesh sieve using either a mortar and pestle or freezer mill. Soil $\mathrm{pH}$ is determined on a 1:2.5 soil:deionized water suspension using a digital $\mathrm{pH}$ meter (Leici PHS-3C, Shanghai, China), and soil electronic conductivity (EC) was determined by a conductivity meter (DDSJ-308A, Hangzhou, Zhejiang, China). Soil organic matter (SOM) was measured colorimetrically after wet digestion by $\mathrm{K}_{2} \mathrm{Cr}_{2} \mathrm{O}_{7}$ [32] . The determination of soil organic carbon (SOC) was carried out using total organic carbon analyzer (TOC-VCPH, Shimadzu, Japan) according to dry combustion method [33]. Total soil phosphorus (TP) was digested by $\mathrm{HF}-\mathrm{HClO}_{4}$ and then measured by the flame photometric method [34]. Available phosphorus (AP) and available nitrogen (AN) were determined according to the method of Page [35]. Total concentration of $\mathrm{HMs}$ was determined by aqua regia $\left(\mathrm{HNO}_{3} / \mathrm{HCl}=1: 3\right)$ and $\mathrm{HClO}_{4}$ extraction method and then determined by flame atomic absorption spectrometry (FAAS, Hitachi Z-2000, Tokyo, Japan). The DTPA-extractable $\mathrm{Pb}$ and $\mathrm{Zn}$ concentrations were extracted from soil with DTPA solution (0.005 mol L ${ }^{-1}$ diethylene triamine penta-acetic acid (DTPA), $0.01 \mathrm{~mol} \mathrm{~L}^{-1} \mathrm{CaCl}_{2}, 0.1 \mathrm{~mol} \mathrm{~L}^{-1}$ triethanolamine) with $\mathrm{pH}$ adjusted to 7.3, and the extracts were analyzed for $\mathrm{Pb}$ and $\mathrm{Zn}$ using FAAS 
method [36]. The quality assurance was achieved using blank reagent and standard reference soil, and the results were determined in triplicate for each soil sample.

\subsection{Soil Enzyme Activities}

Activities of four soil enzymes indicative of $C$ cycle ( $\beta$-glucosidase), $N$ cycle (protease, urease) and $\mathrm{P}$ cycle (alkaline phosphatase) were determined. The activity of $\beta$-glucosidase ( $\left.\mu \mathrm{g} \mathrm{PNP} \mathrm{g}{ }^{-1} \mathrm{~h}^{-1}\right)$ was measured by release and detection of $p$-nitrophenol (PNP) using $p$-nitrophenyl- $\beta$-glucopyranoside as substrate at $400 \mathrm{~nm}$ in an UV spectrophotometer [37]. Protease activity ( $\mu \mathrm{g}$ TYR g ${ }^{-1} \mathrm{~h}^{-1}$ ) was determined as describe by Ladd and Butler [38]. After the addition of casein $(2 \% w / v)$ to $1 \mathrm{~g}$ of substrate, tyrosine (TYR) formed and reacted with Folin-phenol reagent to generate a blue complex that was determined spectrophotometrically at $700 \mathrm{~nm}$. The urease activity $\left(\mu \mathrm{g} \mathrm{NH}_{4}{ }^{+}-\mathrm{N} \mathrm{g}^{-1} \mathrm{~h}^{-1}\right)$ was assayed according to the method of Kandeler and Gerber [39]. After the addition of aqueous (controls) or a buffered urea solution (samples) to $5 \mathrm{~g}$ of soil samples, incubation took place for $2 \mathrm{~h}$ at $37^{\circ} \mathrm{C}$. The measurement was based on the reaction of sodium salicylate with $\mathrm{NH}_{3}$ in the presence of sodium dichloroisocyanurate, which forms a green-colored complex under alkaline $\mathrm{pH}$ conditions. The concentration of $\mathrm{NH}_{4}{ }^{+}-\mathrm{N}$ extracted with $2 \mathrm{M} \mathrm{KCl}$ solution was determined spectrophotometrically at $690 \mathrm{~nm}$. The activity of alkaline phosphatase $\left(\mu \mathrm{g} \mathrm{PNP} \mathrm{g}{ }^{-1} \mathrm{~h}^{-1}\right)$ was measured according to Tabatabai and Bremner [40] after $1 \mathrm{~h}$ soil incubation at $37^{\circ} \mathrm{C}$ with $0.025 \mathrm{M} p$-nitrophenol phosphate disodium in borate buffer at $\mathrm{pH} 10$. The $p$-nitrophenol (PNP) in the filtrate was determined colorimetrically at $410 \mathrm{~nm}$ using a spectrophotometer.

\subsection{DNA Extraction}

Rhizosphere and bulk soil samples were milled to powder using a ceramic pestle and mortar in liquid nitrogen, respectively. DNA was extracted from approximately $0.5 \mathrm{~g}$ of soil using E.Z.N.A. soil DNA kit (Omega Bio-tek Inc., Norcross, GA, USA) according to manufacturer's instructions. The DNA extract quantity and quality were determined by Smartspec Plus Spectrophotometer (Bio-Rad, Hercules, CA, USA) and agarose gel electrophoresis (Invitrogen, Carlsbad, CA, USA). The DNA was then diluted 10-fold with distilled $\mathrm{ddH}_{2} \mathrm{O}$ and used for PCR template.

\subsection{Quantitative PCR}

Bacterial small subunit rRNA gene amplified from total soil DNA extracts with the forward primer Eub338 and reverse primer Eub518 using the method described by Fierer et al. [41]. To estimate bacterial small-subunit rRNA gene abundances, standard curve was generated using a 10-fold serial dilution of a plasmid containing a full-length copy of Escherichia coli 16S rRNA gene. The $25 \mu \mathrm{L}$ qPCR reactions contained $12.5 \mu \mathrm{L} 2 \times$ Taq SYBR Premix Ex Taq ${ }^{\mathrm{TM}}$ II (Takara Biotechnology Co., Ltd., Dalian, China), $0.5 \mu \mathrm{L}$ of each $10 \mu \mathrm{M}$ forward and reverse primers (Invitrogen), and $9.5 \mu \mathrm{L}$ sterile RNase-free water. Standard and environmental DNA samples were added at $2.0 \mu \mathrm{L}$ per reaction. The reaction was carried out on a CFX Connect Real-Time PCR Detection System (Bio-Rad, USA) using a program of $95^{\circ} \mathrm{C}$ for $10 \mathrm{~min}$, followed by 40 cycles of $95^{\circ} \mathrm{C}$ for $30 \mathrm{~s}, 55^{\circ} \mathrm{C}$ for $30 \mathrm{~s}$ and $72{ }^{\circ} \mathrm{C}$ for $30 \mathrm{~s}$ according to our previous study [42]. Specific amplification of the target gene was confirmed on a $1 \%(w / v)$ agarose gel showing the band of the expected size and melting curve analysis resulting in a single peak. Bacterial gene copy numbers were generated using a regression equation for each assay relating the cycle threshold $\left(C_{t}\right)$ value to the known number of copies in the standards. The final copy numbers of bacterial $16 \mathrm{~S}$ rRNA gene were obtained by calibrating against the total DNA concentration extracted and the soil water content (dry weight soil, DWS). All qPCR reactions were run in quadruplicate with the DNA extracted from each soil sample.

\subsection{RFLP Analysis}

Partial bacterial 16S rRNA genes (about $1500 \mathrm{bp}$ ) were amplified from total soil DNA extracts with the universal primer $1492 \mathrm{R}$ and primer $27 \mathrm{~F}$ [43]. The amplifications were performed in a reaction 
volume of $25 \mu \mathrm{L}$ including $12.5 \mu \mathrm{L} 2 \times$ Taq PCR Master Mix (CoWin Biotech Co., Ltd., Beijing, China), $11 \mu \mathrm{L}$ sterile distilled, $0.5 \mu \mathrm{L}$ each primer and $0.5 \mu \mathrm{L}$ DNA template. The thermal cycling conditions consisted of an initial denaturation at $94{ }^{\circ} \mathrm{C}$ for $4 \mathrm{~min}$, and 30 cycles of $94{ }^{\circ} \mathrm{C}$ for $60 \mathrm{~s}, 55^{\circ} \mathrm{C}$ for $60 \mathrm{~s}$, $72{ }^{\circ} \mathrm{C}$ for $90 \mathrm{~s}$ with a final extension at $72{ }^{\circ} \mathrm{C}$ for $10 \mathrm{~min}$ and was run in BioRad PCR cycler (USA). The resulting PCR products were analyzed by $1.5 \%$ agarose gel electrophoresis and purified using a universal DNA purification kit (Tiangen Biotech Co., Ltd., Beijing, China). The purified PCR products were ligated into pGEM-T cloning vector according to manufacturer's instructions (Tiangen Biotech Co., Ltd., Beijing, China). A total of 24 clone libraries (12 for rhizosphere soil and 12 for bulk soil) were constructed in this study. For each library, approximately 50 white positive clones were picked up randomly and then screened for the presence of a complete insert (1500 bp) by reamplification and gel electrophoresis. Only clones with complete inserts were digested $\left(3 \mathrm{~h}, 37^{\circ} \mathrm{C}\right)$ with $5 \mathrm{U}$ of the restriction enzymes MspI and HaeIII and visualized on $4 \%$ agarose gels. Respective fragments were visualized under UV light and classified into two categories depending on the absence and present of bands for statistical analyses ( 0 , no band; 1 , has band). Representative clones of each RFLP patterns were selected and sequenced unidirectionally by GenScript Corporation (Nanjing, China).

\subsection{Data Analysis}

The restriction fragments with different lengths were compared among samples. Although the use of multiple enzyme digests increases the specificity of data generated by RFLP analysis, different organisms can still produce fragments of similar lengths. Therefore, each fragment is assumed to represent different unique operational taxonomic units (OTU), but not necessarily a distinct species. Bacterial 16S rRNA sequence with $>97 \%$ match were classified as the species, the sequences with 95-97\% similarity were identified to genus, and the sequences with $<95 \%$ match were considered as unknown bacteria based on sequences matched in the NCBI GenBank database. Phylogenetic tree was generated with MEGA version 5.0, using the neighbor-joining (NJ) and bootstrap values from 1000 replicates. The 31 gene sequences obtained in the current study had been deposited into the GenBank database with the following accession numbers: KP162186-KP162216.

OTU richness was determined for each sample as the total number of fragments identified in that sample. OTU diversity and evenness for each sample were calculated with the Margalef Index $\left(d_{M a}\right)$ and Simpson Index $(D)$, which were calculated using the following Equations:

$$
\begin{gathered}
d_{M a}=\frac{S-1}{\operatorname{LnN}} \\
D=1-\sum_{i=1}^{s} P_{i}{ }^{2}, P_{i}=\frac{n_{i}}{N}
\end{gathered}
$$

where $S$ is the total number of phylotypes found at each site, $N$ is the total number of clones selected from each clone library, $n_{i}$ is the number of the $i$ th representative sequence in each clone library.

A $t$-test was performed to compare the average values of soil properties, enzyme activities, bacterial abundances between bulk and rhizosphere soils, while pearson correlation coefficients were used to determine their correlations, which were performed by SPSS 16.0 in Windows 7 (SPSS Inc., Chicago, IL, USA). Data expressed in the figures and tables are presented as the means with a standard deviation (SD). A multivariate redundancy analysis (RDA) was performed by Canoco software (version 4.5, Centre for Biometry, Wageningen, The Netherlands) as a direct gradient analysis to explore the relationships among bacterial community compositions and environmental factors. The effect and significance of each environmental factor on the bacterial abundance and diversity were calculated through forward selection and the Monte Carlo permutation test. 


\section{Results}

\subsection{Soil Properties}

The main chemical properties of soil samples collected from different study sites are shown in Table 1 . The soils were all slightly alkaline and soil $\mathrm{pH}$ in rhizosphere soil was significantly lower than bulk soil, ranging from 7.99 (S4) to 8.62 (S2) and from 7.33 (S4) to 7.58 (S2) in bulk and rhizosphere soils, respectively. The EC values at S3 (0.80) and S4 (0.82) in rhizosphere soil were significant higher compared with these in bulk soil. The SOM, SOC, TN, AN and AP contents in both bulk and rhizosphere soils at $\mathrm{S} 5$ were significant lower than these at $\mathrm{S} 1$, and the contents of AN and AP at all study sites tended to be higher in rhizosphere than in bulk soil except for AN at S1 $(14.9 \mathrm{mg} / \mathrm{kg}$ for bulk soil and $16.9 \mathrm{mg} / \mathrm{kg}$ for rhizosphere soil). However, no significant differences could be detected in EC, SOM, SOC, TN, AN and TP between rhizosphere and bulk soils at S1 ( $p>0.05)$.

Table 1. Chemical properties of bulk and rhizosphere soils at different study sites.

\begin{tabular}{|c|c|c|c|c|c|}
\hline \multirow{2}{*}{ Soil Properties } & \multirow{2}{*}{ Soil Type } & \multicolumn{4}{|c|}{ HM Pollution Level } \\
\hline & & Low & Light & Medium & High \\
\hline \multirow{2}{*}{$\mathrm{pH}$} & BS & $8.47 \pm 0.19^{* *}$ & $8.62 \pm 0.14^{* *}$ & $8.35 \pm 0.32 * *$ & $7.99 \pm 0.41 *$ \\
\hline & RS & $7.51 \pm 0.22$ & $7.58 \pm 0.33$ & $7.47 \pm 0.06$ & $7.33 \pm 0.27$ \\
\hline \multirow{2}{*}{$\mathrm{EC}$} & BS & $0.62 \pm 0.05 \mathrm{~ns}$ & $0.60 \pm 0.05 \mathrm{~ns}$ & $0.71 \pm 0.02 * *$ & $0.74 \pm 0.04$ * \\
\hline & RS & $0.69 \pm 0.02$ & $0.66 \pm 0.03$ & $0.80 \pm 0.03$ & $0.82 \pm 0.04$ \\
\hline \multirow{2}{*}{ SOM } & BS & $11.2 \pm 1.78 \mathrm{~ns}$ & $12.3 \pm 1.51 \mathrm{~ns}$ & $8.76 \pm 1.46^{* *}$ & $5.73 \pm 0.75 *$ \\
\hline & RS & $13.7 \pm 1.33$ & $12.1 \pm 1.42$ & $12.5 \pm 0.65$ & $7.90 \pm 1.29$ \\
\hline \multirow{2}{*}{$\mathrm{SOC}$} & BS & $13.1 \pm 2.41 \mathrm{~ns}$ & $12.0 \pm 2.00 *$ & $8.11 \pm 0.61 *$ & $6.75 \pm 1.51^{* *}$ \\
\hline & RS & $15.3 \pm 2.58$ & $14.8 \pm 0.94$ & $12.2 \pm 2.82$ & $12.0 \pm 0.98$ \\
\hline \multirow{2}{*}{$\mathrm{TN}$} & BS & $1.03 \pm 0.15 \mathrm{~ns}$ & $0.95 \pm 0.22 *$ & $0.99 \pm 0.11 \mathrm{~ns}$ & $0.72 \pm 0.04 \mathrm{~ns}$ \\
\hline & RS & $1.34 \pm 0.21$ & $1.30 \pm 0.15$ & $1.30 \pm 0.26$ & $0.83 \pm 0.17$ \\
\hline \multirow{2}{*}{ AN } & BS & $14.9 \pm 1.74 \mathrm{~ns}$ & $14.7 \pm 1.94^{* *}$ & $12.2 \pm 2.78^{*}$ & $9.04 \pm 1.21 *$ \\
\hline & RS & $16.9 \pm 2.35$ & $20.3 \pm 2.29$ & $18.0 \pm 1.91$ & $11.7 \pm 1.55$ \\
\hline \multirow{2}{*}{$\mathrm{TP}$} & BS & $0.66 \pm 0.15 \mathrm{~ns}$ & $0.84 \pm 0.10 \mathrm{~ns}$ & $0.78 \pm 0.13^{*}$ & $0.54 \pm 0.10 \mathrm{~ns}$ \\
\hline & RS & $0.56 \pm 0.07$ & $0.67 \pm 0.13$ & $0.52 \pm 0.11$ & $0.42 \pm 0.07$ \\
\hline \multirow{2}{*}{$\mathrm{AP}$} & BS & $9.01 \pm 2.13^{* *}$ & $8.51 \pm 1.48^{*}$ & $7.98 \pm 1.34^{* *}$ & $4.89 \pm 1.17 *$ \\
\hline & RS & $13.7 \pm 1.03$ & $12.3 \pm 2.18$ & $12.5 \pm 1.62$ & $7.19 \pm 0.73$ \\
\hline \multirow{2}{*}{$\mathrm{TPb}$} & BS & $223 \pm 51.5 \mathrm{~ns}$ & $922 \pm 308 \mathrm{~ns}$ & $2405 \pm 237^{* *}$ & $3396 \pm 976 \mathrm{~ns}$ \\
\hline & RS & $194 \pm 44.0$ & $751 \pm 101$ & $1579 \pm 268$ & $2687 \pm 278$ \\
\hline \multirow{2}{*}{$\mathrm{DPb}$} & BS & $10.2 \pm 1.83 \mathrm{~ns}$ & $46.7 \pm 6.39 \mathrm{~ns}$ & $152 \pm 14.7^{* *}$ & $293 \pm 70.7^{* *}$ \\
\hline & RS & $7.82 \pm 2.02$ & $38.3 \pm 10.2$ & $73.9 \pm 17.0$ & $132 \pm 15.8$ \\
\hline \multirow{2}{*}{$\mathrm{TZn}$} & BS & $88.4 \pm 23.3 \mathrm{~ns}$ & $195 \pm 6.06^{*}$ & $594 \pm 116^{*}$ & $416 \pm 88.8 \mathrm{~ns}$ \\
\hline & RS & $98.3 \pm 23.7$ & $147 \pm 27.8$ & $409 \pm 32.8$ & $329 \pm 77.6$ \\
\hline \multirow{2}{*}{$\mathrm{DZn}$} & BS & $8.94 \pm 1.23 \mathrm{~ns}$ & $24.9 \pm 8.43 \mathrm{~ns}$ & $67.5 \pm 7.49 \mathrm{~ns}$ & $64.8 \pm 10.3 \mathrm{~ns}$ \\
\hline & RS & $12.2 \pm 3.90$ & $20.4 \pm 2.20$ & $75.6 \pm 4.59$ & $60.0 \pm 14.0$ \\
\hline
\end{tabular}

BS, bulk soil; RS, rhizosphere soil; EC, electrical conductivity; SOM, soil organic matter; SOC, soil organic carbon; $\mathrm{TN}$, total nitrogen; $\mathrm{AN}$, available N; TP, total phosphorus; $\mathrm{AP}$, available phosphorus; $\mathrm{TPb}$, total $\mathrm{Pb}$; $\mathrm{TZn}$, total $\mathrm{Zn}$; $\mathrm{DPb}$, DTPA-extractable $\mathrm{Pb}$; DZn, DTPA-extractable Pb. Potential differences in parameters between bulk and rhizosphere soils were analyzed using $t$-test $\left({ }^{* *} p<0.01 ; * p<0.05\right.$; ns, not significant).

The soil HM concentrations had a large variability among different HM pollution levels (Table 1). S4 had the highest HM contamination level, and the total concentrations of $\mathrm{Pb}$ and $\mathrm{Zn}$ were 9.5 and 1.4 times Grade II of the national environmental quality standard for soils (GB 15618-1995), while $\mathrm{S} 1$ was only slightly polluted by $\mathrm{Pb}(223 \mathrm{mg} / \mathrm{kg})$ and $\mathrm{Zn}(88.4 \mathrm{mg} / \mathrm{kg})$. The DTPA-extractable $\mathrm{Pb}$ and $\mathrm{Zn}$ showed the same pattern as total $\mathrm{Pb}$ and $\mathrm{Zn}$. There was an increasing trend in total and 
DTPA-extractable $\mathrm{Pb}$ followed the order $\mathrm{S} 1<\mathrm{S} 2<\mathrm{S} 3<\mathrm{S} 4$, while the total and DTPA-extractable $\mathrm{Zn}$ decreased in the different order of $\mathrm{S} 3>\mathrm{S} 4>\mathrm{S} 2>\mathrm{S} 1$ in both rhizosphere and bulk soil. The concentrations of DTPA-extractable in relation to the total concentrations were $5.53 \%$ for $\mathrm{Pb}$ and $14.3 \%$ for $\mathrm{Zn}$ when all soil samples were taken into account.

The significantly negative correlations among SOM, SOC, TN, AN, AP and total/ DTPA-extractable $\mathrm{Pb}$ could be found in both bulk and rhizosphere soils $(p<0.05)$ except for TN and total $\mathrm{Pb}$ in bulk soil $(p>0.05)$, however, no correlation could be detected among SOM, AN and total/DTPA-extractable Zn in rhizosphere soil $(p>0.05)$. Soil EC was positively correlated with total/DTPA-extractable $\mathrm{Pb}$ and $\mathrm{Zn}$ in both bulk and rhizosphere soils, while $\mathrm{pH}$ only exhibited significantly negative correlation with total and DTPA-extractable $\mathrm{Pb}$ in bulk soil $(p<0.05)$ (Table S1).

\subsection{Soil Enzyme Activities}

Variations of the enzyme activities in bulk and rhizosphere soils samples at different study sites are shown in Figure 1. For bulk soil, the activities of $\beta$-glucosidase, protease and urease decreased by $60.8 \%, 48.3 \%$ and $59.5 \%$, respectively, from light pollution level to high pollution level. On the contrary, the activities of $\beta$-glucosidase, protease and urease reduced by $34.0 \%, 36.9 \%$ and $37.9 \%$, respectively. However, the activities of alkaline phosphatase at bulk and rhizosphere soils were only decreased by $24.0 \%$ and $17.1 \%$, respectively. Both urease and alkaline phosphatase activities in rhizosphere soil were significantly larger than those in bulk soil at different study sites except for activity of urease at medium pollution level. However, no difference could be found in $\beta$-glucosidase activity between light and low pollution levels.
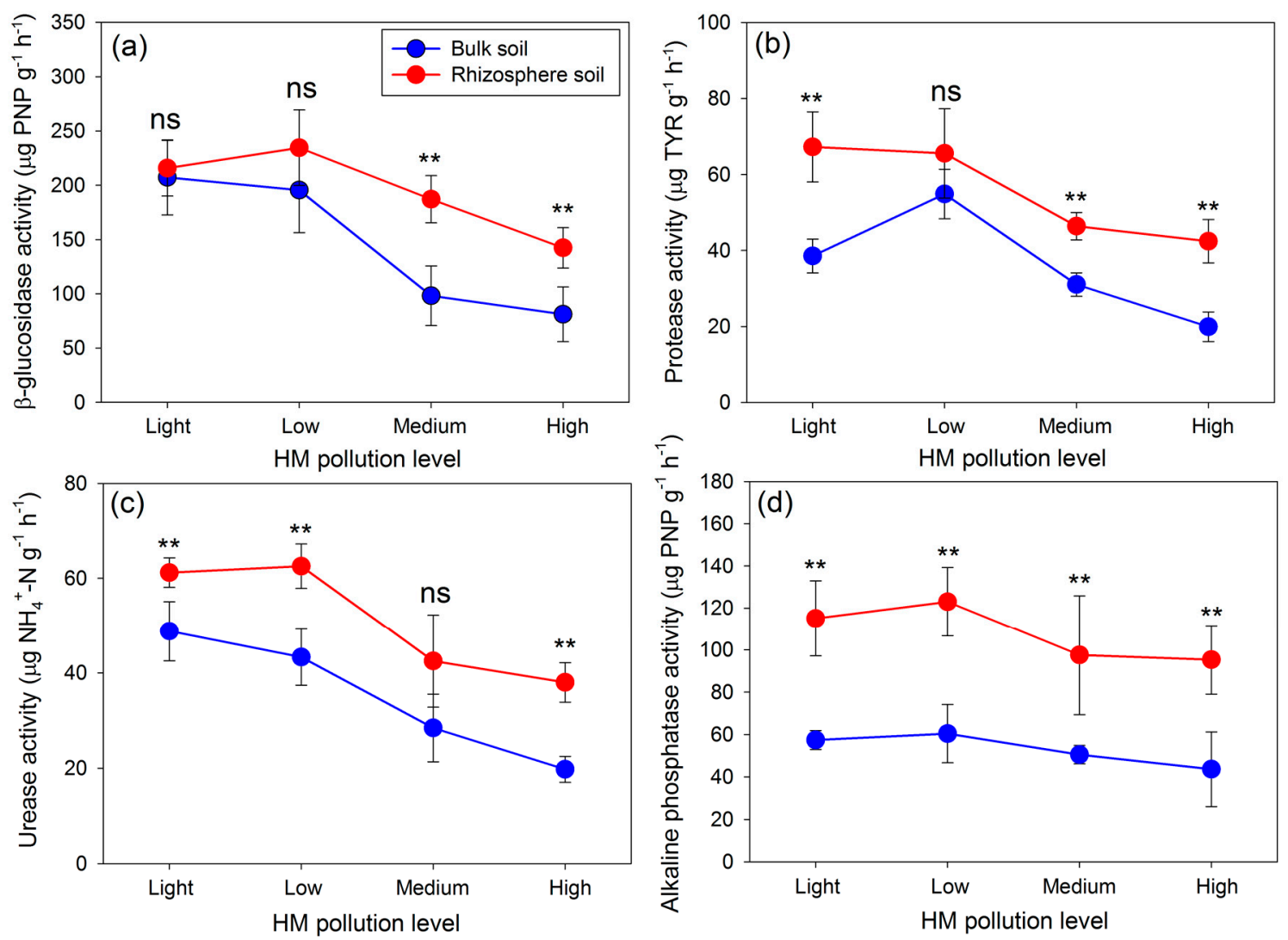

Figure 1. Activities of $\beta$-glucosidase (a), protease (b), urease (c) and alkaline phosphatase (d) in bulk and rhizosphere soils at different HM pollution levels. Potential differences in parameters between bulk and rhizosphere soils were analyzed using $t$-test (** $p<0.01$; ns, not significant). 
The enzyme activities of $\beta$-glucosidase, protease, and urease were positively correlated to $\mathrm{pH}$, SOM, SOC, AN and AP $(p<0.05)$, but had a negatively correlation with EC $(p<0.01)$ in bulk soil. The significantly positive correlations among the enzyme activities of $\beta$-glucosidase, protease, urease and AN, TP and AP in rhizosphere soil $(p<0.05)$ were identified, but no relationship could be detected among them and $\mathrm{pH}(p>0.05)$. Total/DTPA-extractable $\mathrm{Pb}$ and $\mathrm{Zn}$ greatly inhibited the enzyme activities of $\beta$-glucosidase, protease and urease in both bulk and rhizosphere soils $(p<0.05)$, however, no effects could be found on alkaline phosphatase activity $(p>0.05)$ (Table S2).

\subsection{Soil Bacterial Abundance}

The abundance of the soil bacterial community and changes at different HM pollution levels were evaluated using qPCR (Figure 2). The soil bacterial copy number decreased by $73.8 \%$ at bulk soil and $41.6 \%$ at rhizosphere soil, respectively, from light to high pollution levels. The abundance of the soil bacterial community in bulk soil was significantly lower compared with that in rhizosphere soil at low, medium and high pollution levels $(p<0.01)$. However, no difference could be found in bacterial copy number between bulk and rhizosphere soils at light pollution levels $(p>0.05)$.

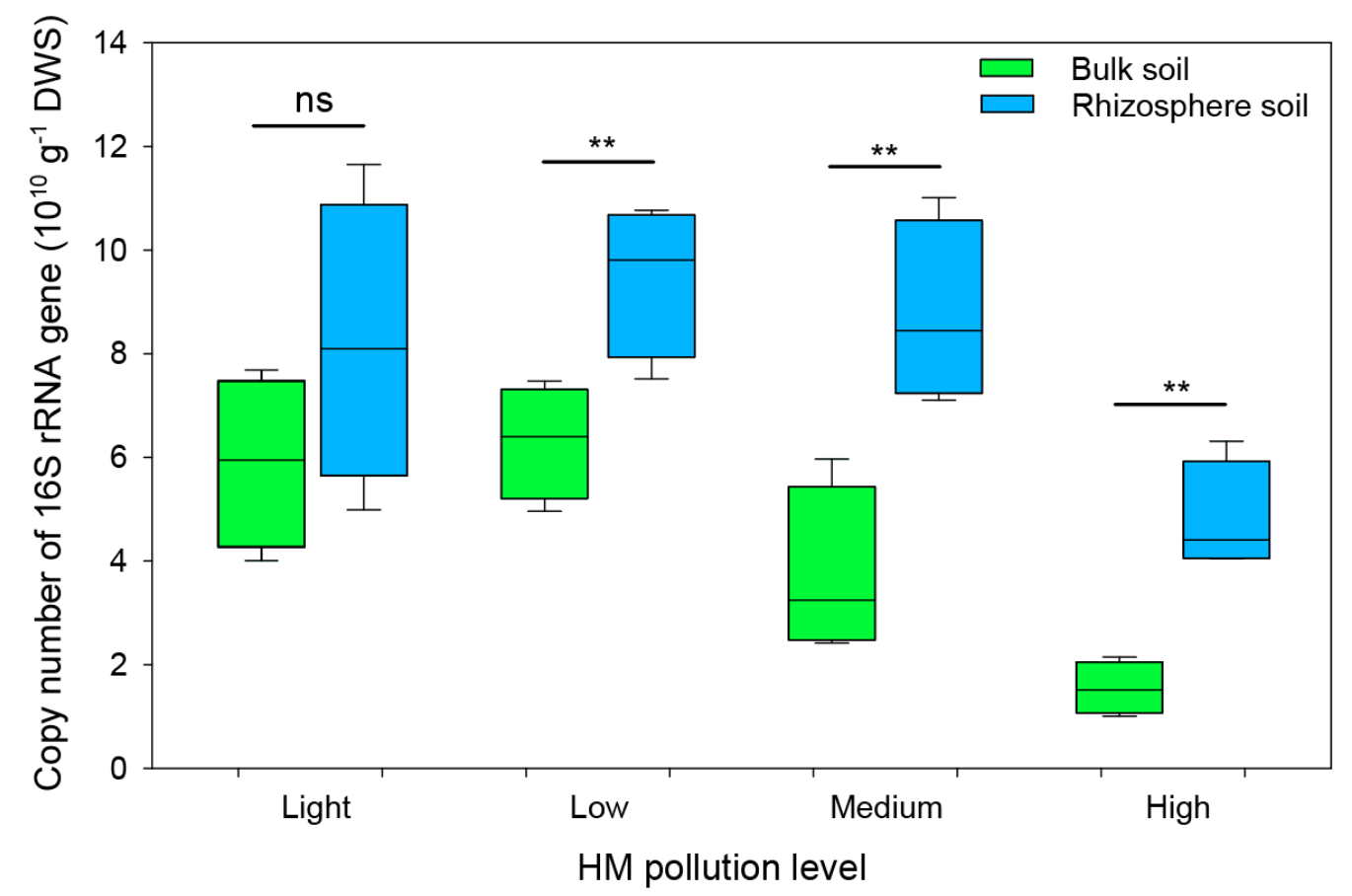

Figure 2. Copy number of bacterial 16S rRNA gene in bulk and rhizosphere soils at different HM pollution levels. Potential differences in parameters between bulk and rhizosphere soils were analyzed using $t$-test ${ }^{* *} p<0.01 ; \mathrm{ns}$, not significant).

Soil $\mathrm{pH}, \mathrm{SOM}, \mathrm{SOC}$ were significantly positively correlated with bacterial abundance in bulk soil $(p<0.05)$; however, no correlation could be detected among them and bacterial abundance in rhizosphere soil $(p>0.05)$. The copy numbers of bacterial 16S rRNA gene in both bulk and rhizosphere soils were significantly inhibited by total/DTPA-extractable Pb concentration $(p<0.05)$, but there was no correlation between bacterial abundance and total/DTPA-extractable $\mathrm{Zn}$ in rhizosphere soil $(p>0.05)$ (Table S3).

\subsection{Phylogenetic Analysis}

The bacterial occurrence was determined in 12 bulk and 12 rhizosphere soil samples. Template DNA was successfully amplified with the universal PCR primers 27F and 1492R, yielding PCR products 
of expected length. In total, 1200 clones were screened and 1171 clones containing insert of correct size of $16 \mathrm{~S}$ rRNA gene were digested by MspI and HaeIII. One to five RFLP representatives were sequenced, yielding 31 bacterial sequences (Table S4). All representatives were deposited to the NCBI database and used for phylogenetic analysis (Figure 3).

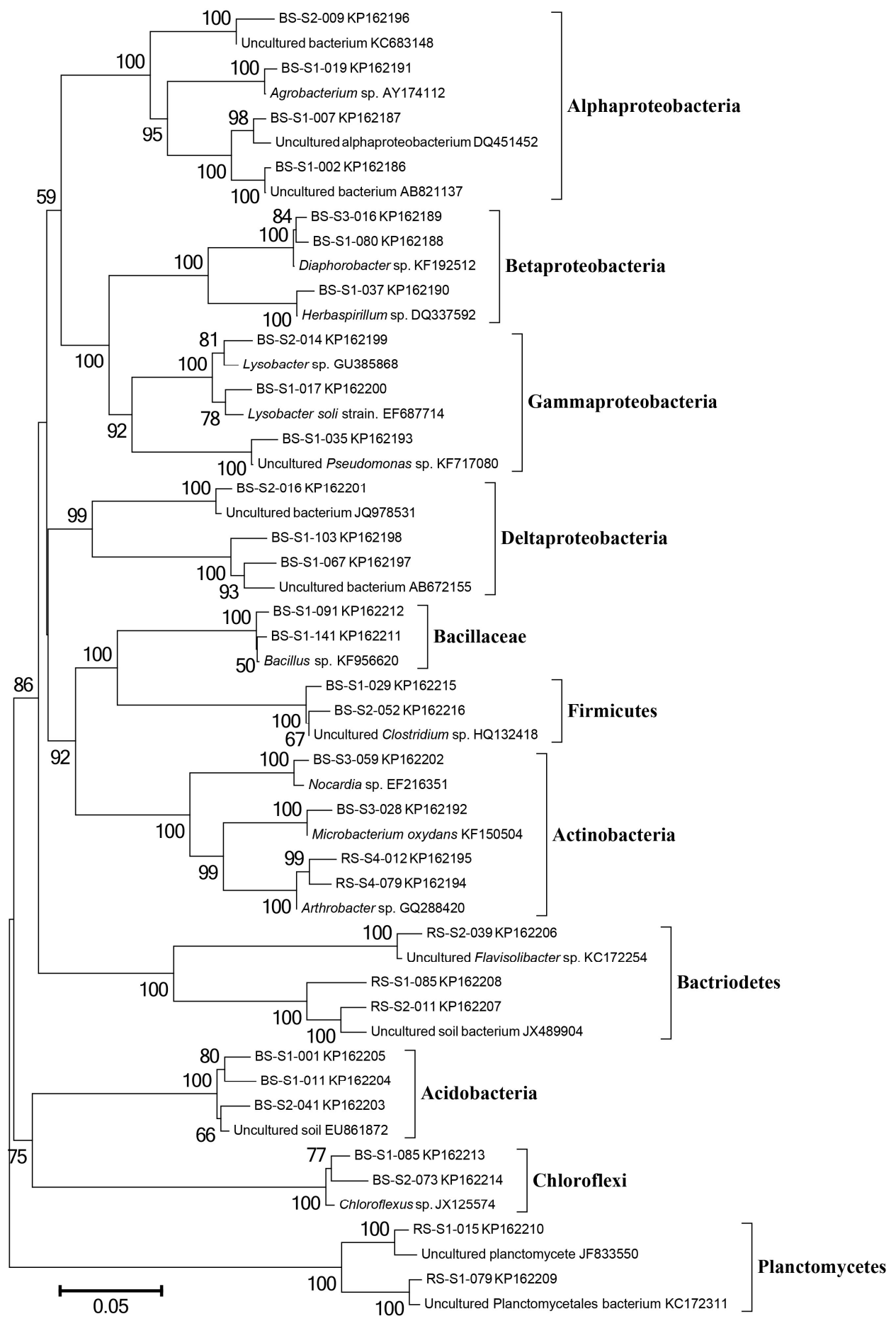

Figure 3. Neighbor-joining bacterial phylogenetic tree construction from partial 16S rRNA sequences. Clones from bulk soils are coded as BS; clones from rhizosphere soils are coded as RS; clones from four study sites are coded as S1, S2, S3 and S4, representing light, low, medium and high pollution levels. The access number for each division is shown on the tree. Bootstrap values (1000 replicates) higher than $50 \%$ are shown. Scale bar represents the $5 \%$ substitution percentage. 
The phylogenetic tree based on 31 representatives of the predominant RFLP types indicated that the bacterial sequences were closely related to 11 known classes: Alphaproteobacteria, Betaproteobacteria, Gammaproteobacteria, Deltaproteobacteria, Bacteroidetes, Bacillacea, Firmicutes, Actinobacteria, Acidobacteria, Chloroflexi and Planctomycetes. Three major classes, namely Alphaproteobacteria, Gammaproteobacteria and Firmicutes, were particularly well represented, accounting for $54.0-84.0 \%$ of the sequenced flora. Whatever the pollution level, these two classes were found in both bulk and rhizosphere soils samples with high percentage at four study sites (Figure 3). Another class, namely Bacillacea was found in rhizosphere soil samples, accounting for $28.7-37.3 \%$ of the sequenced flora.

\subsection{Bacterial Communities in Rhizosphere Soil}

The bacterial composition was dominated by Alphaproteobacteria, Gammaproteobacteria, and Firmicutes across all 12 soil samples analyzed, while other taxa presented at relatively lower abundance (Figure 4). Of the bacterial classes detected by the RFLP analysis, eight were found in rhizosphere soil associated with R. pseudoacacia grown at light pollution level, with an average of 2.7 classes per sample, while only five classes were detected at high pollution level, with an average 1.7 classes per sample. The class of Alphaproteobacteria and Bacillacea followed a clear decreasing gradient with increasing HM pollution levels, ranging from $7.3-26.0 \%$ and $14.7-19.3 \%$ of all clones, respectively. However, the percentage of Gammaproteobacteria and Firmicutes increased with increasing of soil HM concentrations, ranging from $18.0-34.7 \%$ and $10.7-22.0 \%$ of all clones, respectively. Actinobacteria and Chloroflexi could not be found in the rhizosphere soil at different study sites. It is interesting to notice that Betaproteobacteria and Planctomycetes were only found at light and low pollution levels, however, with increasing of HM concentrations, they disappeared at medium and high pollution levels (Figure 4).

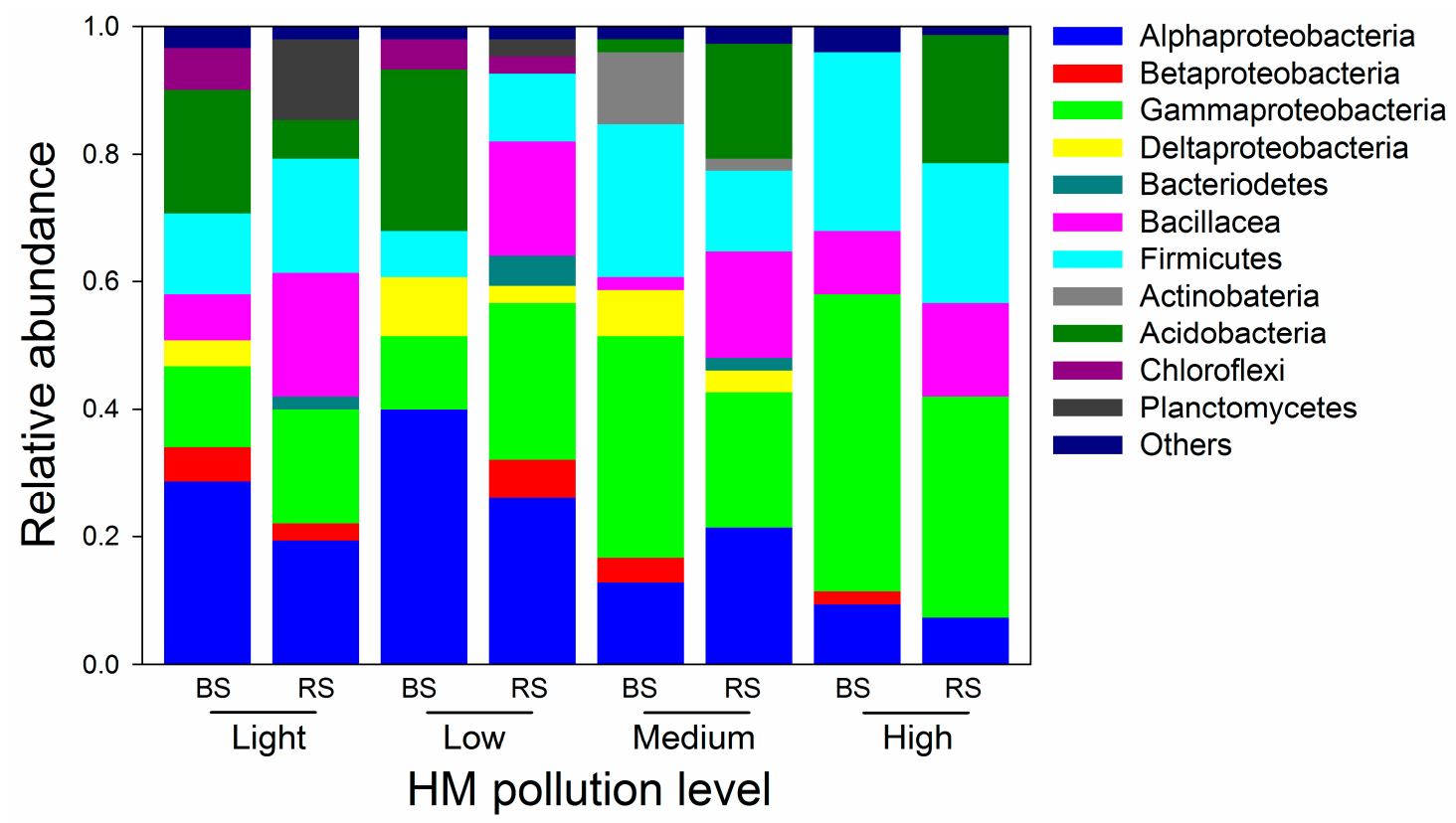

Figure 4. Bacterial composition in bulk soil (BS) and rhizosphere soil (RS) at different HM pollution levels. The relative abundance of each class based on $16 \mathrm{~S}$ rRNA gene analysis is expressed in percentage.

\subsection{Bacterial Communities in Bulk Soil}

Bulk soil presented a characteristic bacterial community that was different from that of the rhizosphere soil. Significant differences were found in the relative abundance of four bacterial classes. Class Gammaproteobacteria is of particular interest as it was found more frequently in bulk soils compared 
with that in rhizosphere soil samples, accounting for $46.7 \%$ of all clones at high pollution level. However, Bacillacea was seldom found in bulk soil samples, and only $2.0-10.0 \%$ of all clones had this class at different HM pollution levels (S1-S4). Two classes, namely Bacteroidetes and Planctomycetes could not be found in the bulk soil samples collected from different study sites. The three most abundant bacterial classes in rhizosphere soil samples collected from four study sites were Alphaproteobacteria, Gammaproteobacteria and Firmicutes. The class of Alphaproteobacteria followed a clear decreasing gradient with increasing of HM pollution levels, ranging from 40.0-9.3\% of all clones. However, the percentage of Gammaproteobacteria and Firmicutes increased with increasing of soil HM concentrations, ranging from $11.7-46.3 \%$ and $7.3-28.0 \%$ of all clones, respectively. Two classes, namely Deltaproteobacteria and Acidobacteria, could be found in the rhizosphere soil samples collected from light, low and medium pollution levels, however, with increasing HM concentrations, these two classes disappeared at high pollution level (Figure 4).

\subsection{Bacterial Diversity Index}

The bacterial diversity index of Species richness $(S)$, Margalef $\left(d_{M a}\right)$ and Simpson index $(D)$ varied in either bulk or rhizosphere soil associated with $R$. pseudoacacia grown at different HM pollution levels (Figure 5). The $S$ and $d_{M a}$ in bulk and rhizosphere soils decreased by $73.8 \%$ and $41.6 \%$, respectively, from light and high pollution levels. There was no difference in $S, d_{M a}$ and $D$ between bulk and rhizosphere soils at light pollution level $(p>0.05)$, although the significant difference in $D$ could be detected between bulk and rhizosphere soils at medium pollution level $(p<0.05)$.

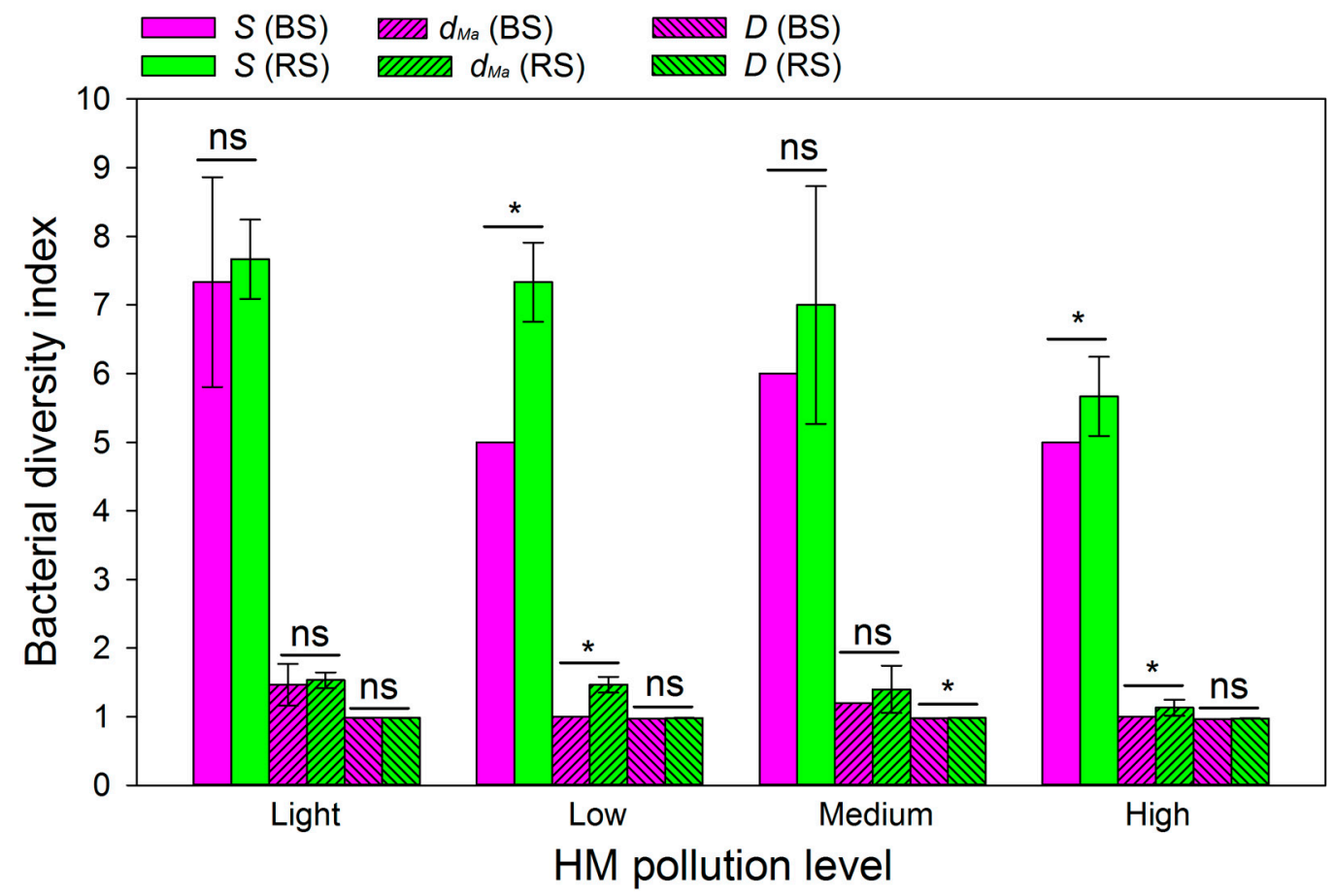

Figure 5. The bacterial diversity index of Species richness $(S)$, Margalef $\left(d_{M a}\right)$ and Simpson index $(D)$ in bulk and rhizosphere soils associated with R. pseudoacacia grown at different HM pollution levels. Potential differences in parameters between bulk and rhizosphere soils were analyzed using $t$-test (* $p<0.05 ;$ ns, not significant).

\section{Discussion}

The maximum total concentrations of $\mathrm{Pb}$ and $\mathrm{Zn}$ in both bulk and rhizosphere soils at $\mathrm{S} 1 \mathrm{did}$ not exceed the corresponding limits of the China Environmental Quality Standard for Soils (GB15618-1995, Grade II), suggesting that the HM concentrations at S1 were normal (Table 1). However, total Pb 
concentration at S2, S3 and S4 were 2.63, 6.87 and 9.70 times in bulk soil or 2.14, 4.51 and 7.68 times in rhizosphere soil above grade II of GB15618-1995 respectively, indicating that these sites were heavily polluted by HM according to either national grade II standard. Soil Zn concentration satisfied grade II quality at S1 and S2, but exceed the limits of GB15618-1995 at S3 and S4 in both bulk and rhizosphere soils. Our results reflected that significant accumulations of HM in soils could be attributed to smelting and mining activities, which probably pose potential risks to human health and the environment [6].

It has been widely accepted that availability rather than total HM concentration determines the toxic effects of a metal on biological systems [44]. In the current study, HM availability was considered as the ratio of the DTPA-extractable concentration to the corresponding total concentration to characterize their toxicity. $\mathrm{Pb}$ availability in either bulk soil (12.7\%) or rhizosphere soil (16.0\%) was significantly lower compared with that of Zn (Figure S2), suggesting the higher solubility of Zn than that of $\mathrm{Pb}$ in soils, which was consistent with the finding of Fritsch et al. [45] in HM contaminated soils around mining area. However, it is interesting to note that the availability of Pb was significantly higher in bulk soil than that in rhizosphere soil at medium and high pollution levels, while a contrary tendency for $\mathrm{Zn}$ could be detected at medium pollution level (Figure S2). The results indicated that different types of HMs had various patterns of behavior and mobility between bulk and rhizosphere soils and along HM contamination gradient. $\mathrm{Zn}$ is an essential metal for plant growth and plays an important role in photosynthesis and enzyme composition for protein synthesis [46]; however, $\mathrm{Pb}$ is a non-essential element and has toxic effects on plant growth (membrane damage and oxidative stress) [47]. Therefore, plants may develop their own strategy to survive in HM polluted soil: reducing availability of toxic $\mathrm{HM}(\mathrm{Pb})$ in rhizosphere and preventing the translocation of $\mathrm{Pb}$ from soil to the aerial parts of plants, which was consistent with our previous study [24,31]. Various studies have indicated that plant root exudates could react with HM ions and affected metal solubility, mobility and phytoavailability [48]. Luo et al. [49] reported that plant had ability to release low molecular weight organic acids such as oxalate into the soil, forming complexes with $\mathrm{Pb}$ and then immobilizing its availability in rhizosphere soil.

Soil enzymes are the main regulators of the biochemical processes within the soil environment and have been widely used as indicators for environmental quality, such as productivity, fertility and nutrient cycling potential [50]. Our study showed that the activities of $\beta$-glucosidase, protease and urease in both bulk and rhizosphere soils were significantly inhibited by total/DTPA-extractable $\mathrm{Pb}$ and $\mathrm{Zn}$ concentrations (Table S2), suggesting that the active center of these enzymes might be inactivated by metal onions, and thereby preventing them from carrying out their hydrolytic action [51]. This was consistent with the results found by other studies for slightly alkaline soil, which reported that $\beta$-glucosidase, protease and urease activities are sensitive bioindicators of soil degradation caused by HM contamination [52]. However, alkaline phosphatase activity was less affected by heavy mental pollution level (Table S2), suggesting that in tolerant bacteria this enzyme was well protected and kept its functional activity in HM contaminated soils [53]. On the other hand, the activities of $\beta$-glucosidase, protease and alkaline phosphatase in rhizosphere soil were significantly higher than those in bulk soil (Figure 1). The rhizosphere effect was likely due to physiological activities of plant roots under HM stress condition, which could cause the roots to release large amounts of enzymes into the rhizosphere soil [54]. Meanwhile, microorganisms adhering plant roots were able to secrete various enzymes to the surrounding soil unceasingly. Therefore, higher enzyme activity may be attributed to larger bacterial copy number in rhizosphere soil (Figure 2), resulting in different enzyme activity profiles between the bulk and rhizosphere soils [55].

HM had toxic effects on the growth, morphology and metabolism of microorganism in soil, through functional disturbance, protein denaturation and destruction of the integrity of cell membranes. However, some metal-tolerant bacteria can still survive in soils heavily polluted with HMs, showing great potential for biotechnological and bioremediation applications [56]. The relative abundance of the clones related to each of the major groups was calculated based on the number of clone sequences, and the results showed that the bacterial community structure was highly diverse and heterogeneous 
in bulk and rhizosphere soils at different HM pollution levels (Figure 4). The dominant bacterial classes found in both bulk and rhizosphere soils were Alphaproteobacteria, Gammaproteobacteria and Firmicutes. The results were consistent with Mendez et al. [57], who found that the soil bacterial communities were dominated by Proteobacteria (Alphaproteobacteria, Betaproteobacteria, and Gammaproteobacteria) and Firmicutes in an abandoned semiarid lead-zinc mine tailing. The class of Alphaproteobacteria was also widely detected in soils highly polluted by toxic metals, such as $\mathrm{Cu}$, $\mathrm{Zn}$ and $\mathrm{Cd}[58,59]$. Zhu et al. [60] investigated the bacterial composition of sediments contaminated with HMs in Xiangjiang River (Zhuzhou, Hunan Province, China), and found that the dominant families belonged to Alphaproteobacteria, Betaproteobacteria and Firmicutes. The current study confirmed that they were also the most dominant classes in semiarid lead-zinc mine region in the Northwest of China (Figure 4). Gammaproteobacteria also presented to be high percentage $(26.3 \%$ for bulk soil, 26.7\% for rhizosphere soil) in HM polluted soils. Gomez-Balderas et al. [61] reported a similar proportion of Gammaproteobacteria (30\%) in soils polluted with Zn and Cd. Our results were also consistent with that a previous study which reported that Gammaproteobacteria isolated from the rhizosphere soil of willows had high resistance to $\mathrm{Zn}$ contamination [62].

In the present study, we confirmed that rhizosphere soil harbored much larger abundant and diversity of bacterial community compared with bulk soil (Figures 2, 4 and 5). The bacterial $16 \mathrm{~S}$ rRNA copy number, Species richness $(S)$, Margalef $\left(d_{M a}\right)$ were significantly higher in rhizosphere soil than these in bulk soil. However, no difference could be found in Simpson index $(D)$ between bulk and rhizosphere soils. The phenomenon could be partly explained by that plant roots could release different types of organics (exudates, secretions, sloughed off cells) to rhizosphere soil, and provide a relatively stable environment for the growth of microorganisms [63]. Besides, HM could be immobilized in soil when it formed complexes with root exudates, particularly mucilage components, producing much less or non-toxic HM [49]. This explanation was supported by our results that the availability of $\mathrm{Pb}$ in rhizosphere soil was significantly lower compared with that in bulk soil, as shown in Figure S2. However, the detailed information about the components of root exudates from $R$. pseudoacacia required to be further studied to reveal the mechanisms of root exudates for immobilizing HMs in rhizosphere soil.

Although the large differences in bacterial abundance, composition and diversity between bulk and rhizosphere soils and among different study sites could be detected, redundancy analysis (RDA) indicated that HM concentration was not the only environmental parameters influencing bacterial abundance and composition in the present study (Figure 6). Numbers in brackets represented the percentage of variation of the data explained by each factor. RDA axis 1 explained $89.2 \%$ of the total variation and RDA axis 2 explains $7.8 \%$ of the total variation in bulk soil, while RDA axis 1 explained $67.3 \%$ of the total variation and RDA axis 2 explains $18.9 \%$ of the total variation in rhizosphere soil, respectively. The multivariate analysis showed that, apart from total/DTPA-extractable Pb concentrations, soil EC, pH and SOM content greatly influenced bacterial abundance and diversity in bulk soil (Figure 6a). Detailed information indicated that, in rhizosphere soil, the bacterial abundance and community was highly associated with total/DTPA-extractable Pb, soil pH, EC, TP content (Figure 6b). Although environmental factors influencing bacterial community structure are varied, several studies have found that $\mathrm{HM}$ pollutions $(\mathrm{Pb}$ and $\mathrm{Cd}$ ) could be the major environmental variables affecting bacterial diversity [64]. Soil $\mathrm{pH}$ has been proved to be one of the most important environmental factors determining the movement, availability, and toxicity HM, due to its strong effects on solubility of metals in soil [65]. Our study provided the evidence that soil $\mathrm{pH}$ was negatively corrected with HM availability $(p<0.05)$ (Table S1). The current study also found that SOM had significantly negative correlations with soil total/DTPA-extractable $\mathrm{Pb}, \mathrm{Zn}$ and $\mathrm{Pb}$ availability in bulk soil $(p<0.05)$, but no correlation between SOM and HM availability could be detected in rhizosphere soil $(p>0.05)$ (Table S1). Soil pH and SOM content altered bacterial community diversity and composition probably through influencing HM availability and changing the toxic effects on growth and metabolism of microorganisms in polluted soils. On the other hand, SOM was able to 
influence the function of the soil microbial community via affecting soil structural properties and availability of nutritional substrates [66]. Soil EC has been used as a good indicator of soil stress level and is generally correlated with soil $\mathrm{pH}$. In agreement with our findings, Kim et al. [67] suggested that the bacterial community in intensively cultivated greenhouse soils could be particularly affected by soil $\mathrm{pH}$ and EC. Soil $\mathrm{pH}$ had also shown one of the most important environmental factors impacting bacterial abundance and diversity in natural and agricultural ecosystems [68]. However, it should be noted that the four plots in each HM pollution level might not be appropriate replicates from the view of large scale, and other environmental factors (vegetation, stage of plant growth, etc.) which was not mentioned in the study probably had great effects on soil property, bacterial abundance and community. Therefore, further research is still needed to improve the understanding of detailed correlations among other environmental factors and their specific effects on soil property, enzyme activity, bacterial abundance and community in bulk and rhizosphere soils along a gradient of HM contamination in forest ecosystem.
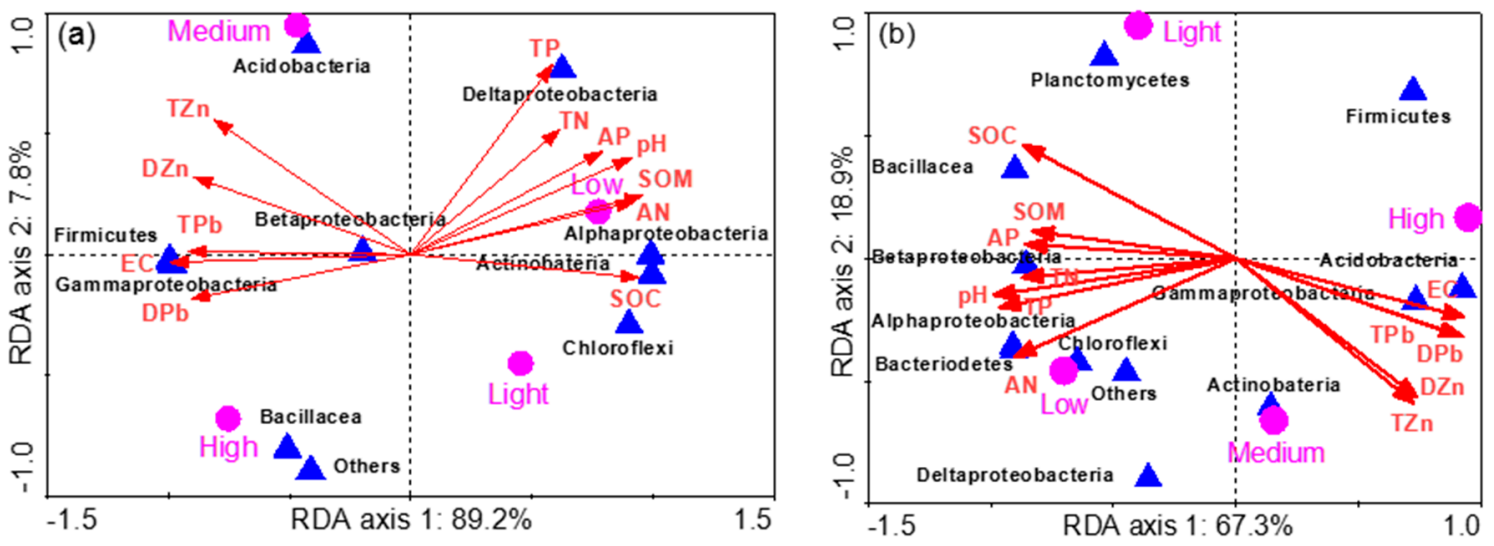

Figure 6. Redundancy analysis (RDA) of the correlations between the bacteria taxa and soil physiochemical properties in bulk soil (a) and rhizosphere soil (b) at different HM pollution levels. The arrow length and direction correspond to the variance that can be explained by the environmental and response variables. The direction of an arrow reflects the extent to which the given factor is influenced by each RDA variable. The perpendicular distance between the abundance of bacterial taxa and environmental variable axes in the plot indicates their correlations. The smaller the distance, the stronger the correlation. EC, electrical conductivity; SOM, soil organic matter; SOC, soil organic carbon; TN, total nitrogen; $\mathrm{AN}$, available nitrogen; $\mathrm{TP}$, total phosphorus; $\mathrm{AP}$, available phosphorus; $\mathrm{TPb}$, total $\mathrm{Pb}$; $\mathrm{TZn}$, total $\mathrm{Zn}$; $\mathrm{DPb}$, DTPA-extractable Pb; DZn, DTPA-extractable Zn.

\section{Conclusions}

It has been widely accepted that the physical, chemical, and biological properties of rhizosphere soil were significantly different from those of the surrounding bulk soil. This study was conducted to illustrate the rhizosphere effect on soil properties, enzyme activities and bacterial community associated with Robinia pseudoacacia in HM contaminated soils, Northwest China. The results showed that the $\mathrm{pH}$ of rhizosphere soil was lower than that of bulk soil $(p<0.05)$. In contrast, soil organic matter (SOM), available nitrogen (AN) and phosphorus (AP) contents in rhizosphere soil were significantly higher than those in bulk soil at HM contaminated sites $(p<0.05)$. The activities of $\beta$-glucosidase, protease, urease and alkaline phosphatase in rhizosphere soil across all study sites increased by $47.5 \%, 64.1 \%$, $52.9 \%$ and $103.8 \%$, respectively. Bacterial $16 \mathrm{~S}$ rRNA copy number in rhizosphere soil was significantly higher than that in bulk soil $(p<0.05)$, and was significantly inhibited by total/DTPA-extractable Pb concentrations $(p<0.01)$. Alphaproteobacteria, Gammaproteobacteria and Firmicutes were the most dominant groups of bacteria at different study sites. The bacterial diversity index of Species richness (S) and Margalef $\left(d_{M a}\right)$ were significantly higher in rhizosphere soil compared with that in bulk soil, 
although no difference could be found in Simpson index $(D)$ between bulk and rhizosphere soils $(p>0.05)$. Redundancy analysis (RDA) showed that soil $\mathrm{pH}, \mathrm{EC}, \mathrm{SOM}$ and total/DTPA-extractable $\mathrm{Pb}$ concentrations were the most important variables affecting bacterial abundance, composition and diversity $(p<0.05)$. The information and insights obtained on the properties of soil nutrient content, enzyme activities, bacterial abundance and community in bulk and rhizosphere soils will enhance our understanding of rhizosphere effect and improve remediation of HM contaminated soils in forest ecosystem.

Supplementary Materials: The following are available online at www.mdpi.com/1999-4907/8/11/430/s1.

Acknowledgments: The study was supported by the National Key Research and Development Program of China (2017YFD0600104), the National Natural Science Foundation of China (41671268), Shaanxi Science and Technology Innovation Project Plan (2016KTCL02-07), and the Fundamental Research Funds for the Central Universities (2412017QD022).

Author Contributions: Y.Y. and M.T. conceived and designed the experiments; Y.Y. and Y.B. carried out the experiments; Y.Y., M.D., Y.C. and J.W. analyzed the data; Y.Y. and M.D. wrote the paper.

Conflicts of Interest: The authors declare no conflict of interest.

\section{References}

1. Arriagada, C.A.; Herrera, M.A.; Ocampo, J.A. Beneficial effect of saprobe and arbuscular mycorrhizal fungi on growth of Eucalyptus globulus co-cultured with Glycine max in soil contaminated with heavy metals. J. Environ. Manag. 2007, 84, 93-99. [CrossRef] [PubMed]

2. Bhargava, A.; Carmona, F.F.; Bhargava, M.; Srivastava, S. Approaches for enhanced phytoextraction of heavy metals. J. Environ. Manag. 2012, 105, 103-120. [CrossRef] [PubMed]

3. Solgi, E.; Esmaili-Sari, A.; Riyahi-Bakhtiari, A.; Hadipour, M. Soil contamination of metals in the three industrial estates, Arak, Iran. Bull. Environ. Contam. Toxcol. 2012, 88, 634-638. [CrossRef] [PubMed]

4. Alloway, B.J. Soil processes and the behaviour of metals. In Heavy Metals in Soils; Alloway, B.J., Ed.; Blackie Academic and Professional: London, UK, 1995; pp. 11-37.

5. Moreira, H.; Marques, A.P.; Rangel, A.O.; Castro, P.M. Heavy metal accumulation in plant species indigenous to a contaminated Portuguese site: Prospects for phytoremediation. Water Air Soil Pollut. 2011, 221, 377-389. [CrossRef]

6. Li, Z.; Ma, Z.; van der Kuijp, T.J.; Yuan, Z.; Huang, L. A review of soil heavy metal pollution from mines in China: Pollution and health risk assessment. Sci. Total Environ. 2014, 468, 843-853. [CrossRef] [PubMed]

7. Shen, F.; Liao, R.; Ali, A.; Mahar, A.; Guo, D.; Li, R.; Xining, S.; Awasthi, M.K.; Wang, Q.; Zhang, Z. Spatial distribution and risk assessment of heavy metals in soil near a $\mathrm{Pb} / \mathrm{Zn}$ smelter in Feng County, China. Ecotoxicol. Environ. Saf. 2017, 139, 254-262. [CrossRef] [PubMed]

8. Zhuang, W.; Gao, X. Integrated assessment of heavy metal pollution in the surface sediments of the Laizhou Bay and the coastal waters of the Zhangzi Island, China: Comparison among typical marine sediment quality indices. PLoS ONE 2014, 9, e94145. [CrossRef] [PubMed]

9. Järup, L. Hazards of heavy metal contamination. Br. Med. Bull. 2003, 68, 167-182. [CrossRef] [PubMed]

10. Burns, R.G. Enzyme activity in soil: Location and a possible role in microbial ecology. Soil Biol. Biochem. 1982, 14, 423-427. [CrossRef]

11. Das, S.K.; Varma, A. Role of enzymes in maintaining soil health. In Soil Enzymology; Shukla, G., Varma, A., Eds.; Springer-Verlag: Berlin, Germany, 2011; pp. 25-42.

12. Xian, Y.; Wang, M.; Chen, W. Quantitative assessment on soil enzyme activities of heavy metal contaminated soils with various soil properties. Chemosphere 2015, 139, 604-608. [CrossRef] [PubMed]

13. Vig, K.; Megharaj, M.; Sethunathan, N.; Naidu, R. Bioavailability and toxicity of cadmium to microorganisms and their activities in soil: A review. Adv. Environ. Res. 2003, 8, 121-135. [CrossRef]

14. Brookes, P.C. The use of microbial parameters in monitoring soil pollution by heavy metals. Biol. Fertil. Soils 1995, 19, 269-279. [CrossRef]

15. Liao, M.; Huang, C.Y. Effect of combined pollution by heavy metals on soil enzymatic activities in areas polluted by tailings from Pb-Zn-Ag mine. J. Environ. Sci. 2005, 17, 637-640. 
16. Giller, K.E.; Witter, E.; Mcgrath, S.P. Toxicity of heavy metals to microorganisms and microbial processes in agricultural soils: A review. Soil Biol. Biochem. 1998, 30, 1389-1414. [CrossRef]

17. Acosta-Martinez, V.; Tabatabai, M.A. Enzyme activities in a limed agricultural soil. Biol. Fertil. Soils 2000, 31, 85-91. [CrossRef]

18. Versaw, W.K.; Harrison, M.J. A chloroplast phosphate transporter, PHT2;1, influences allocation of phosphate within the plant and phosphate-starvation responses. Plant Cell 2002, 14, 1751-1766. [CrossRef] [PubMed]

19. Yang, Z.X.; Liu, S.Q.; Zhang, D.W.; Feng, S.D. Effects of cadium, zinc and lead on soil enzyme activities. J. Environ. Sci. 2006, 18, 1135-1141. [CrossRef]

20. Smalla, K.; Wieland, G.; Buchner, A.; Zock, A.; Parzy, J.; Kaiser, S.; Roskot, N.; Heuer, H.; Berg, G. Bulk and rhizosphere soil bacterial communities studied by denaturing gradient gel electrophoresis: Plant-dependent enrichment and seasonal shifts revealed. Appl. Environ. Microbiol. 2001, 67, 4742-4751. [CrossRef] [PubMed]

21. Hinsinger, P.; Bengough, A.G.; Vetterlein, D.; Young, I.M. Rhizosphere: Biophysics, biogeochemistry and ecological relevance. Plant Soil 2009, 321, 117-152. [CrossRef]

22. Phillips, R.P.; Fahey, T.J. Tree species and mycorrhizal associations influence the magnitude of rhizosphere effects. Ecology 2006, 87, 1302-1313. [CrossRef]

23. Liu, D.; Fang, S.; Tian, Y.; Chang, S.X. Nitrogen transformations in the rhizosphere of different tree types in a seasonally flooded soil. Plant Soil Environ. 2014, 60, 249-254.

24. Yang, Y.; Liang, Y.; Ghosh, A.; Song, Y.; Chen, H.; Tang, M. Assessment of arbuscular mycorrhizal fungi status and heavy metal accumulation characteristics of tree species in a lead-zinc mine area: Potential applications for phytoremediation. Environ. Sci. Pollut. Res. 2015, 22, 13179-13193. [CrossRef] [PubMed]

25. Hu, Y.H.; Nan, Z.R.; Su, J.Q.; Wang, N. Heavy metal accumulation by poplar in calcareous soil with various degrees of multi-metal contamination: Implications for phytoextraction and phytostabilization. Environ. Sci. Pollut. Res. 2013, 20, 7194-7203. [CrossRef] [PubMed]

26. Moser, A.; Rötzer, T.; Pauleit, S.; Pretzsch, H. The urban environment can modify drought stress of small-leaved lime (Tilia cordata Mill.) and black locust (Robinia pseudoacacia L.). Forests 2016, 7, 71. [CrossRef]

27. Xu, Z.Y.; Tang, M.; Chen, H.; Ban, Y.H.; Zhang, H.H. Microbial community structure in the rhizosphere of Sophora viciifolia grown at a lead and zinc mine of northwest China. Sci. Total Environ. 2012, 435, 453-464. [CrossRef] [PubMed]

28. Yao, S.J.; Tian, M.M.; Wu, S.L. Mineral resources exploitation and sustainable development of Fengxian County in Shaanxi Province. Miner. Res. Geol. 2004, 18, 470-475.

29. Ban, Y.H.; Tang, M.; Chen, H.; Xu, Z.Y.; Zhang, H.H.; Yang, Y.R. The response of dark septate endophytes (DSE) to heavy metals in pure culture. PLoS ONE 2012, 7, e47968. [CrossRef] [PubMed]

30. Yang, Y.; Song, Y.; Scheller, V.H.; Ghosh, A.; Ban, Y.; Chen, H.; Tang, M. Community structure of arbuscular mycorrhizal fungi associated with Robinia pseudoacacia in uncontaminated and heavy metal contaminated soils. Soil Biol. Biochem. 2015, 86, 146-158. [CrossRef]

31. Yang, Y.; Han, X.; Liang, Y.; Ghosh, A.; Chen, J.; Tang, M. The combined effects of arbuscular mycorrhizal fungi (AMF) and lead $(\mathrm{Pb})$ stress on $\mathrm{Pb}$ accumulation, plant growth parameters, photosynthesis, and antioxidant enzymes in Robinia pseudoacacia L. PLoS ONE 2015, 10, e0145726. [CrossRef] [PubMed]

32. Nelson, D.W.; Sommers, L.E. Total carbon, organic carbon and organic matter. In Methods of Soil Analysis; Page, A.L., Ed.; American Society of Agronomy and Soil Science Society of America: Madison, WI, USA, 1982; pp. 539-579.

33. Bremner, J.M.; Mulvaney, C.S. Total nitrogen. In Methods of Soil Analysis; Page, A.L., Ed.; American Society of Agronomy and Soil Science Society of America: Madison, WI, USA, 1982; pp. 595-624.

34. Jackson, M.L. Soil Chemical Analysis; Prentice-hall Inc.: Englewood Cliffs, NJ, USA, 1958; pp. 111-133.

35. Page, A.L.; Miller, R.H.; Keeney, D.R. Methods of soil analysis. In Chemical and Microbiological Properties; American Society of Agronomy: Madison, WI, USA, 1982.

36. Lindsay, W.L.; Norvell, W.A. Development of a DTPA soil test for zinc, iron, manganese, and copper. Soil Sci. Soc. Am. J. 1978, 42, 421-428. [CrossRef]

37. Eivazi, F.; Tabatabai, M.A. Glucosidases and galactosidases in soils. Soil Biol. Biochem. 1988, 20, 601-606. [CrossRef]

38. Ladd, J.N.; Butler, J.H.A. Short-term assays of soil proteolytic enzyme activities using proteins and dipeptide derivatives as substrates. Soil Biol. Biochem. 1972, 4, 19-30. [CrossRef] 
39. Kandeler, E.; Gerber, H. Short-term assay of soil urease activity using colorimetric determination of ammonium. Biol. Fertil. Soils 1988, 6, 68-72. [CrossRef]

40. Tabatabai, M.A.; Bremner, J.M. Use of $p$-nitrophenyl phosphate for assay of soil phosphatase activity. Soil Biol. Biochem. 1969, 1, 301-307. [CrossRef]

41. Fierer, N.; Jackson, J.A.; Vilgalys, R.; Jackson, R.B. Assessment of soil microbial community structure by use of taxon-specific quantitative PCR assays. Appl. Environ. Microbiol. 2005, 71, 4117-4120. [CrossRef] [PubMed]

42. Xu, Z.; Ban, Y.; Li, Z.; Chen, H.; Yang, R.; Tang, M. Arbuscular mycorrhizal fungi play a role in protecting roots of Sophora viciifolia Hance. From $\mathrm{Pb}$ damage associated with increased phytochelatin synthase gene expression. Environ. Sci. Pollut. Res. 2014, 21, 12671-12683. [CrossRef] [PubMed]

43. Lane, D.J. 16S/23S rRNA sequencing. In Nucleic Acid Techniques in Bacterial Systematics; Stackebrandt, E., Goodfellow, M., Eds.; Wiley: Chichester, UK, 1991; pp. 115-175.

44. Olaniran, A.O.; Balgobind, A.; Pillay, B. Bioavailability of heavy metals in soil: Impact on microbial biodegradation of organic compounds and possible improvement strategies. Int. J. Mol. Sci. 2013, 14, 10197-10228. [CrossRef] [PubMed]

45. Fritsch, C.; Giraudoux, P.; Cœurdassier, M.; Douay, F.; Raoul, F.; Pruvot, C.; Waterlot, C.; De Vaufleury, A.; Scheifler, R. Spatial distribution of metals in smelter-impacted soils of woody habitats: Influence of landscape and soil properties, and risk for wildlife. Chemosphere 2010, 81, 141-155. [CrossRef] [PubMed]

46. Bonanno, G.; Lo Giudice, R. Heavy metal bioaccumulation by the organs of Phragmites australis (common reed) and their potential use as contamination indicators. Ecol. Indic. 2010, 10, 639-645. [CrossRef]

47. Rodriguez, E.; da Conceição Santos, M.; Azevedo, R.; Correia, C.; Moutinho-Pereira, J.; de Oliveira, J.M.P.F.; Dias, M.C. Photosynthesis light-independent reactions are sensitive biomarkers to monitor lead phytotoxicity in a Pb-tolerant Pisum sativum cultivar. Environ. Sci. Pollut. Res. 2015, 22, 574-585. [CrossRef] [PubMed]

48. Guo, G.; Zhou, Q.; Ma, L.Q. Availability and assessment of fixing additives for the in situ remediation of heavy metal contaminated soils: A review. Environ. Monit. Assess. 2006, 116, 513-528. [CrossRef] [PubMed]

49. Luo, Q.; Wang, S.; Sun, L.N.; Wang, H. Metabolic profiling of root exudates from two ecotypes of Sedum alfredii treated with Pb based on GC-MS. Sci. Rep. 2017, 7, 39878. [CrossRef] [PubMed]

50. Puglisi, E.; Del Re, A.A.M.; Rao, M.A.; Gianfreda, L. Development and validation of numerical indexes integrating enzyme activities of soils. Soil Biol. Biochem. 2006, 38, 1673-1681. [CrossRef]

51. De Santiago-Martín, A.; Cheviron, N.; Quintana, J.R.; González, C.; Lafuente, A.L.; Mougin, C. Metal contamination disturbs biochemical and microbial properties of calcareous agricultural soils of the Mediterranean area. Arch. Environ. Contam. Toxicol. 2013, 64, 388-398. [CrossRef] [PubMed]

52. Garcia-Gil, J.C.; Plaza, C.; Soler-Rovira, P.; Polo, A. Long-term effects of municipal solid waste compost application on soil enzyme activities and microbial biomass. Soil Biol. Biochem. 2000, 32, 1907-1913. [CrossRef]

53. Hussein, K.A.; Joo, J.H. Heavy metal resistance of bacteria and its impact on the production of antioxidant enzymes. Afr. J. Microbiol. Res. 2013, 7, 2288-2296.

54. Xiao, S.; You, H.; You, W.; Liu, J.; Cai, C.; Wu, J.; Ji, Z.; Zhan, S.; Hu, Z.; Zhang, Z.; et al. Rhizosphere and bulk soil enzyme activities in a Nothotsuga longibracteata forest in the Tianbaoyan National Nature Reserve, Fujian Province, China. J. For. Res. 2017, 28, 521-528. [CrossRef]

55. Ai, C.; Liang, G.; Sun, J.; Wang, X.; Zhou, W. Responses of extracellular enzyme activities and microbial community in both the rhizosphere and bulk soil to long-term fertilization practices in a fluvo-aquic soil. Geoderma 2012, 173, 330-338. [CrossRef]

56. Piotrowska-Seget, Z.; Cycoń, M.; Kozdroj, J. Metal-tolerant bacteria occurring in heavily polluted soil and mine spoil. Appl. Soil Ecol. 2005, 28, 237-246. [CrossRef]

57. Mendez, M.O.; Neilson, J.W.; Maier, R.M. Characterization of a bacterial community in an abandoned semiarid lead-zinc mine tailing site. Appl. Environ. Microbiol. 2008, 74, 3899-3907. [CrossRef] [PubMed]

58. Sandaa, R.A.; Torsvik, V.; Enger, Ø. Influence of long-term heavy-metal contamination on microbial communities in soil. Soil Biol. Biochem. 2001, 33, 287-295. [CrossRef]

59. Gremion, F.; Chatzinotas, A.; Harms, H. Comparative 16S rRNA and 16S rRNA sequence analysis indicates that Actinobacteria might be a dominant part of the metabolically active bacteria in heavy metal-contaminated bulk and rhizosphere soil. Environ. Microbiol. 2003, 5, 896-907. [CrossRef] [PubMed] 
60. Zhu, J.; Zhang, J.; Li, Q.; Han, T.; Xie, J.; Hu, Y.; Chai, L. Phylogenetic analysis of bacterial community composition in sediment contaminated with multiple heavy metals from the Xiangjiang River in China. Mar. Pollut. Bull. 2013, 70, 134-139. [CrossRef] [PubMed]

61. Gomez-Balderas, C.D.; Cochet, N.; Bert, V.; Tarnaud, E.; Sarde, C.O. 16S rRNA analysis of bacterial communities associated with the hyper accumulator Arabidopsis halleri grown on a $\mathrm{Zn}$ and Cd polluted soil. Eur. J. Soil Biol. 2014, 60, 16-23. [CrossRef]

62. Kuffner, M.; Puschenreiter, M.; Wieshammer, G.; Gorfer, M.; Sessitsch, A. Rhizosphere bacteria affect growth and metal uptake of heavy metal accumulating willows. Plant Soil 2008, 304, 35-44. [CrossRef]

63. Paterson, E.; Hall, J.M.; Rattray, E.A.S.; Griffiths, B.S.; Ritz, K.; Killham, K. Effect of elevated $\mathrm{CO}_{2}$ on rhizosphere carbon flow and soil microbial processes. Glob. Chang. Biol. 1997, 3, 363-377. [CrossRef]

64. Khan, S.; Hesham, A.E.L.; Qiao, M.; Rehman, S.; He, J.Z. Effects of Cd and Pb on soil microbial community structure and activities. Environ. Sci. Pollut. Res. 2010, 17, 288-296. [CrossRef] [PubMed]

65. Zeng, F.; Ali, S.; Zhang, H.; Ouyang, Y.; Qiu, B.; Wu, F.; Zhang, G. The influence of pH and organic matter content in paddy soil on heavy metal availability and their uptake by rice plants. Environ. Pollut. 2011, 159, 84-91. [CrossRef] [PubMed]

66. Bending, G.D.; Turner, M.K.; Jones, J.E. Interactions between crop residue and soil organic matter quality and the functional diversity of soil microbial communities. Soil Biol. Biochem. 2002, 34, 1073-1082. [CrossRef]

67. Kim, J.M.; Roh, A.S.; Choi, S.C.; Kim, E.J.; Choi, M.T.; Ahn, B.K.; Kim, S.K.; Lee, Y.H.; Joa, J.H.; Kang, S.S.; et al. Soil $\mathrm{pH}$ and electrical conductivity are key edaphic factors shaping bacterial communities of greenhouse soils in Korea. J. Microbiol. 2016, 54, 838-845. [CrossRef] [PubMed]

68. Bartram, A.K.; Jiang, X.; Lynch, M.D.; Masella, A.P.; Nicol, G.W.; Dushoff, J.; Neufeld, J.D. Exploring links between $\mathrm{pH}$ and bacterial community composition in soils from the Craibstone Experimental Farm. FEMS Microbiol. Ecol. 2014, 87, 403-415. [CrossRef] [PubMed]

(C) 2017 by the authors. Licensee MDPI, Basel, Switzerland. This article is an open access article distributed under the terms and conditions of the Creative Commons Attribution (CC BY) license (http://creativecommons.org/licenses/by/4.0/). 